\title{
Perineal Wound Identification With Maternity Cool Gel Pad (MCGP) Care Interventions
}

\author{
Bina Melvia Girsang ${ }^{1}$, Eqlima Elfira ${ }^{2}$, Farida Linda Sari Siregar ${ }^{3}$ \\ ${ }^{1}$ Department of Maternity and Child Nursing Universitas Sumatera Utara \\ ${ }^{2}$ Department Surgical Medical Nursing Universitas Sumatera Utara \\ ${ }^{3}$ Department of Maternity and Child Nursing Universitas Sumatera Utara \\ Jalan Dr. T. Mansur No.9, Padang Bulan, Kec. Medan Baru, Kota Medan, Sumatera Utara \\ Email: binamelvia@usu.ac.id
}

\begin{abstract}
Abstrak
Persalinan ibu postpartum dengan indikasi tindakan episiotomi akan mengalami tingkat nyeri yang lebih tinggi. Trauma jalan lahir ini bersifat akut dan diharapkan dapat segera pulih dalam jangka waktu yang pendek, dapat diukur, dan tanpa komplikasi yang serius. Tujuan penelitian ini adalah untuk mengidentifikasi proses penyembuhan luka perineum ibu postpartum. Intervensi dilakukan pada 31 ibu postpartum dengan pemilihan menggunakan teknik purposive sampling. Maternity cool gel pad (MCGP) yang diaplikasikan pada intervensi perawatan luka perineum pada hari ke-2 dan ke-3 paska melahirkan menunjukkan proses penyembuhan luka yang diobservasi dengan menggunakan alat ukur REEDA dan dianalisis menggunakan uji T one sample. Perbaikan skala gambaran perbaikan luka dari rerata skor REEDA $(10,81 \pm 2,98)$ terjadi pada seluruh luka responden penelitian pada post intervensi $(5,32 \pm 1,73)$. Intervensi maternity cool gel pad membantu proses penyembuhan luka pada data post intervensi $(P<0,005)$. Hasil kajian tersebut dapat menjadi petunjuk respon inflamasi secara lokalisasi di luka perineum, namun dibutuhkan penelitian lebih lanjut untuk mengobservasi dampak penyembuhan luka perineum dengan kombinasi metode yang dapat membantu mengevaluasi proses perbaikan luka perineum yang dapat dilakukan oleh ibu secara mandiri di rumah.
\end{abstract}

Kata Kunci: cool gel; perineum; postpartum

\begin{abstract}
Postpartum mothers with an indication of episiotomy will experience a higher level of pain. This birth canal trauma is acute and is expected to recover in a short period of time, can be measured, and without serious complications. The aim of this study was to identify the healing process of postpartum maternal perineal wounds. The intervention was carried out on 31 postpartum mothers with the selection using purposive sampling technique. Maternity cool gel pad (MCGP) which was applied to the perineal wound care intervention on the 2nd and 3rd day after delivery showed the wound healing process was observed using the REEDA measuring instrument and analyzed using the $T$ one sample test. The repair of the wound repair scale from the mean REEDA score $(10.81 \pm 2.98)$ occurred in all wounds of the study respondents at post intervention (5.32 \pm 1.73$)$. Maternity cool gel pad intervention assisted the wound healing process in post intervention data $(P<0.005)$. The results of this study can be indicative of an inflammatory response locally in perineal wounds, but further research is needed to observe the impact of perineal wound healing with a combination of methods that can help evaluate the perineal wound repair process that can be done by mothers independently at home.
\end{abstract}

Keywords: cool gel; perineum; postpartum 
Article info:

Article submitted on October 02, 2020

Articles revised on November 15, 2020

Articles received on December 06, 2020

DOI: $h$ ttp://dx.doi.org/10.21927/jnki.2020.8(4).279-285

\section{INTRODUCTION}

Tears of the perineal tissue at delivery, either spontaneously or with an episiotomy, in $70 \%$ of cases require perineal suture treatment. Postpartum mothers with an indication of episiotomy will experience a higher level of pain (1), more than $60 \%$ of mothers with pain complaints are experienced with a classification of pain levels ranging from moderate to severe pain within five days of delivery (2). Indications for episiotomy are performed with the aim of widening the birth canal, and minimizing severe perineal tears due to larger expulsion of the baby (3).

Episiotomy is a tear in the perineum which is a trauma that can be considered as serious treatment. Trauma to the birth canal is acute and is expected to recover in a short time, can be measured, and without serious complications. Delayed wound healing process can be caused by various factors that can affect the mother individually, and requires handling care during the postnatal period, especially at home $(4,5)$. The most felt experience of the effects of laceration of the birth canal by the mother is pain (6). The pain felt by postpartum mothers can directly affect the bonding process between mother and baby, so that it has an impact on the breastfeeding process, the limitations of the mother in caring for the baby, mobilization disorders which affect the healing process (7).

Based on several research results it has been suggested that there are several approaches in the treatment of perineal wounds that include pharmacological methods such as the use of analgesic and non-pharmacological drugs such as cold therapy $(8,9)$. Several pharmacological practices in the management of perineal wounds are reported not to significantly address the response to pain and discomfort of postpartum mothers due to their limited use. This is evidence that perineal wound management services are needed in maternity care (10).

The use of cold therapy using ice packs has previously been studied reported to delay healing of perineal wounds (11). Its hard, stiff, wet texture causes discomfort, and can cause ice burns $(12,13)$.. This problem is often ignored by health workers, so that health workers are needed to actively promote effective ways of postpartum mothers in the treatment of perineal wounds so that they can easily adapt to their role as mothers (9). Cold gel pad is a method that is considered more efficient, because it does not cause side effects, is comfortable and practical when used and does not cause ice burns (14). Cold therapy produces local anesthetic effects and changes in collagen produced by the peripheral nerve block mechanism. The viscoelastic changes of collagen and the reduction of muscle flexibility have the effect of decreasing the edema of the perineal wound (15).

\section{MATERIALS AND METHODS}

This research is a randomized interventional study to identify wounds from maternity cool gel pad intervention, using a quasi experimental design, one group pre post test only design. The sampling technique was carried out by purposive sampling, in 31 postnatal mothers with normal delivery with episiotomy, wound grade 1-2. This research was conducted in the community working area of Pantai Cermin District, Serdang Badagai Regency with an average number of 
episiotomy deliveries of 150 births per month. The intervention procedure was carried out once a day for 2 consecutive days from the 2 nd to 3 rd postpartum day. Perineal wound care was carried out with a maternal cool gel pad (MCGP) for 10 minutes and was observed categorically using the REEDA scale.

The sampling technique was purposive sampling, namely by the process of selecting a group of people or elements with which the research was conducted. After explaining the research objectives in detail, willingness was accepted by signing the consent form. Study subjects who met the inclusion criteria, postnatal mothers during day 2, and 3 , gave birth with an indication of episiotomy. The exclusion criteria for this study were those with diabetes, eclampsia, sexually transmitted diseases, puerperal sepsis, grade 3 and 4 perineal tears, instrumental delivery, lower segment caesarean section, and disabilities.

Administrative approval and permission was obtained from the institution with letter number 01.611 / KEPK / POLTEKKES KEMENKES MEDAN 2020. Written consent from research subjects (informed consent) was obtained after explaining the intervention carried out for the purpose of the study. The principle of confidentiality and anonymity is explained to the research subjects and guaranteed by the researcher. The tool used in the intervention is the maternity cool gel pad. Data analysis was performed using SPSS 16.0 software, referring to the one-sample $t$ test as a statistical test in processing data on differences in the perineal wound repair process in postpartum mothers on the first day and the second day.

\section{RESULTS AND DISCUSSION}

The characteristic of postpartum mothers in this study have majority of ages are 20-25 years old $(48.4 \%)$, with the majority of them being Moslem (96.8\%), and Javanese ethnic (87.1\%).

Postpartum mothers need perineal care assisted by nurses after delivery process. Nurses have an important role in evaluating perineal wounds such as signs of infection, edema, hematoma, and the importance of educating mothers on perineal hygiene in order to prevent infection in the postpartum period (16). Another important role is to introduce nonpharmacological interventions to postpartum mothers that can be carried out by mothers as part of postpartum care $(16,17)$.

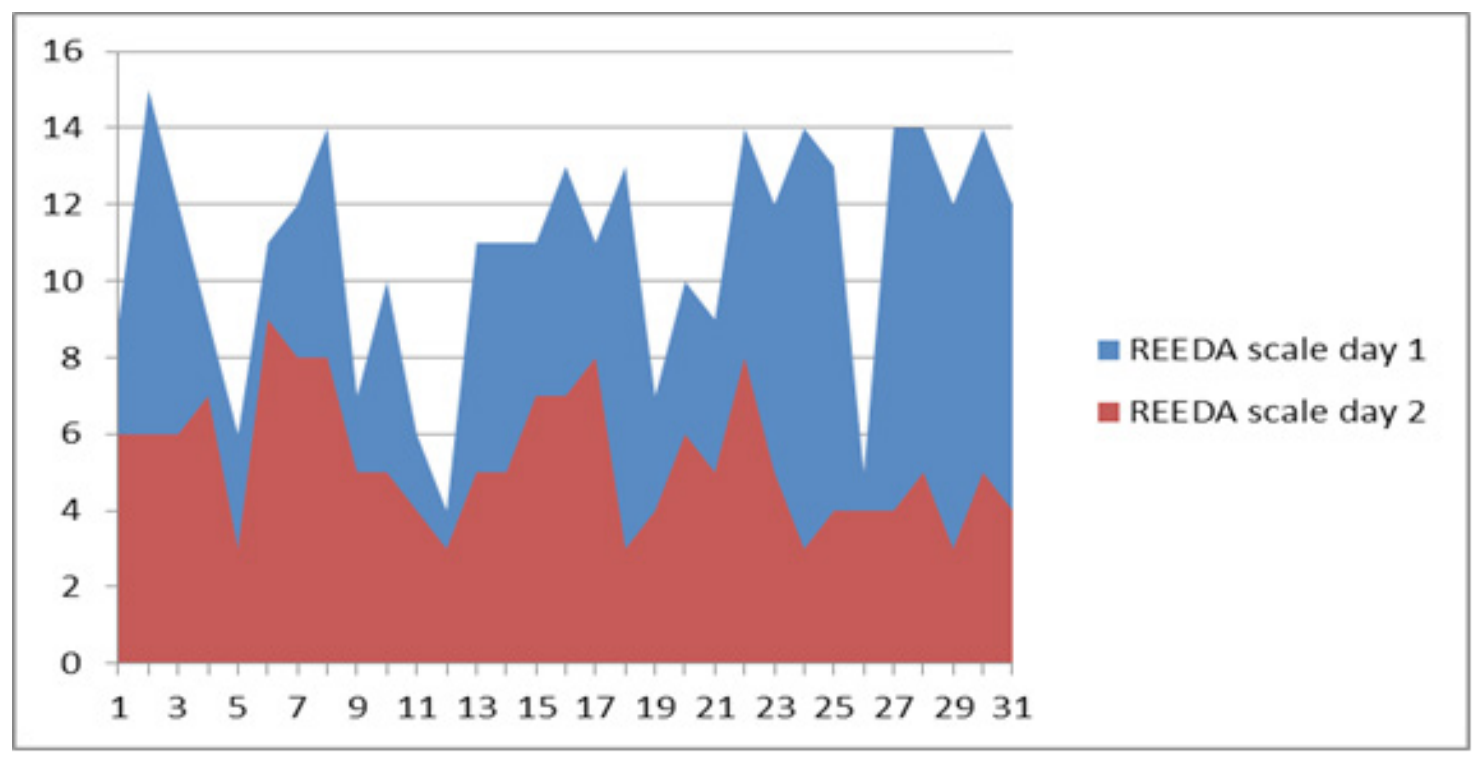

Figure 1. Distribution of Perineal Wound Characteristics by REEDA Assesment On Day-1 and Day-2 
The assessment of wound characteristics with REEDA scale shows a picture of the difference in scale values on the first and second day of assessment (Figure 1). Research proves that the discomfort of postpartum mothers in doing cold sitz baths is due to the wide surface area of the skin that is exposed to cold temperatures, and is at risk of experiencing ice burns. Local application of cold therapy to perineal wounds is the method preferred by postparum mothers (18).

The assessment of the wound area is an important study to estimate the evolution of wound healing and the professionalism of health workers to be able to change the method of treating perineal wounds (19). An accurate holistic assessment of the patient and the wound will provide an understanding of the primary care goals resulting in improved perineal wound repair.

There are differences in the appearance of wounds on the first day and the second day after the intervention using the maternity cold gel pad (Table 1). The picture of redness in the perineal wound on the first day there is a change with an average difference of 0.96 , the difference in the edema scale is 1.13 , the difference in echymosis is 0.8 , the difference in discharge is 1.35 , and Approximetry with a difference of 1.32. Based on the assessment of the wound healing process with a score range of 0-15 with a category rating of 0-3 scale. In this study, there were 31 postpartum mothers without the use of pain medications and had grade 2 laceration characteristics. Based on the wound healing scores on the second postpartum day, the difference in the total REEDA scores on the first and second days was 5.49 .

The process of healing the perineal wound is an important thing to pay attention to after a normal delivery. The incidence of infection can occur if the management of perineal wound care is not carried out properly so that it has an impact on the bonding attachment process of mothers and babies who will experience delays, are hampered by breastfeeding, the treatment process is time-consuming, and will cost a lot of money. This research shows the application of a cold compress was applied using a cool gel pad medium designed in such a way as to provide comfort during perineal compression.

The gel material in the maternity cool gel pad is a tool that is considered more comfortable to use and does not provide excessive cold sensation and can cause hyperalgesia in the wound area (20). The process of wound healing with the REEDA assessment also shows data that supports the perineal wound healing process as evidenced by the difference in the REEDA scale on the first day and the second day. Perineal care management is part of the task of assisting nurses in post-partum mothers, starting from debriefing discharge planning regarding perineal care at midwifery services to assisting mothers in treating perineal wounds while at home. This was done by the researcher by documenting the results of the perineal wound care intervention using the maternity cool gel pad. The hope of the

Table 1. One Sample T-Test Results on The REEDA Scale on The First and Second Post-Intervention Days

\begin{tabular}{lcccc}
\hline \multirow{2}{*}{ Scale } & \multicolumn{2}{c}{ Day-1 } & \multicolumn{2}{c}{ Day - 2 } \\
\cline { 2 - 5 } & Mean \pm SD & pValue & Mean \pm SD & pValue \\
\hline Redness & $2,22 \pm 0,85$ & 0,000 & $1,26 \pm 0,57$ & 0,000 \\
Edema & $2,10 \pm 0,79$ & 0,000 & $0,97 \pm 0,54$ & 0,000 \\
Echymosis & $1,74 \pm 0,85$ & 0,000 & $0,94 \pm 0,62$ & 0,000 \\
Discharge & $2,87 \pm 0,42$ & 0,000 & $1,52 \pm 1,33$ & 0,000 \\
Approximation & $1,97 \pm 0,98$ & 0,000 & $0,65 \pm 0,79$ & 0,000 \\
REEDA Score & $10,81 \pm 2,98$ & 0,000 & $5,32 \pm 1,73$ & 0,000 \\
\hline
\end{tabular}


applied management is to prevent infection in the perineal wound caused by wrong knowledge, attitudes and treatment actions $(21,22)$

Postpartum mothers need to be convinced that perineal wounds require a process in the healing process (23). Boyle (2014) states in his scientific work the importance of managing perineal trauma from an early age by implementing muscle contraction and relaxation strategies that aim to increase the revascularization of damaged muscle fibers so as to support the perineal wound healing process. The process of healing soft tissue wounds to the perineum begins with pelvic floor muscle exercises in the first 24 hours. The formulation of appropriate perineal wound management techniques is still important to be explored and becomes a basic care service that can be applied in obstetrics and social maternity services and will empower postpartum mothers in carrying out perineal wound care with correct management that is easy to do (24).

\section{CONCLUSION AND RECOMMENDATION}

According to some researchers, treating perineal wounds using cold therapy can accelerate the wound healing process. Maternity cool gel pad (MCGP) applied to perineal wound care interventions on the 2 nd and 3 rd day postpartum helped the wound healing process in the post intervention data $(P<0.005)$. Cooling localized to the perineal wound has a significant impact on the perineal wound healing process. Further research is still needed as a method and operational procedure that can be applied to postpatum mothers in carrying out perineal wound management independently at home.

\section{REFERENCES}

1. Kettle $C$, Dowswell $T$, Ismail KM. Continuous and interrupted suturing techniques for repair of episiotomy or second-degree tears. Cochrane Database Syst Rev. 2012 Nov 14;
2. Wong HS, Kong $\mathrm{H}$, Hospital A. Article in Hong Kong medical journal $=$ Xianggang yi xue za zhi / Hong Kong Academy of Medicine [Internet]. 2006 [cited 2020 Feb 8]. Available from: http://hdl.handle.net/10722/45495

3. Fraser M, Midwifery MC-, 2003 undefined. Myles text book for midwives. just.edu.jo [Internet]. [cited 2019 Oct 2]; Available from: http://www.just.edu.jo/CoursesAndLabs/ Midwifery (3) Theory_MW 419/MW 419.doc

4. Steen M. Perineal tears and episiotomy: How do wounds heal? Br J Midwifery. 2007;15(5).

5. Steen M, Cooper K. A new device for the treatment of perineal wounds. J Wound Care [Internet]. 1999 Feb [cited 2020 Feb 7];8(2):87-90. Available from: http:// www.magonlinelibrary.com/doi/10.12968/ jowc.1999.8.2.25843

6. Steen M. Understanding perineal pain: Women's descriptions. Vol. 16, British Journal of Midwifery. MA Healthcare Ltd; 2008. p. 383-93.

7. Steen M, Midwifery PM-E-B, 2007 undefined. Ice packs and cooling gel pads versus no localised treatment for relief of perineal pain: a randomised controlled trial. go.gale.com [Internet]. [cited 2020 Feb 7]; Available from: https://go.gale.com/ps/i.do?id=GALE\%7CA 167108900\&sid=googleScholar\&v=2.1\&it=r \&linkaccess=abs\&issn=14794489\&p=AONE $\& s w=w$

8. Adresi $Y$, Pinar $Y$, Üniversitesi Sağlık Bilimleri Fakültesi Hemşirelik Bölümü $B$, Pınar G, Doğan N, Algıer L, et al. Annelerin doğum sonu konforunu etkileyen faktörler Factors that affecting mothers' postnatal comfort [Internet]. Vol. 36, Dicle Med J Cilt. [cited 2020 Nov 23]. Available from: https://dergipark.org.tr/en/pub/dicletip/ issue/4693/63986

9. MJV Oliveira S, Silva FM, Riesco ML. Comparison of application times for ice 
packs used to relieve perineal pain after normal birth: a randomised clinical trial. J Clin Nurs [Internet]. 2012 Dec [cited 2020 Feb 13];21(23-24):3382-91. Available from: https://onlinelibrary.wiley.com/doi/ abs/10.1111/j.1365-2702.2012.04195.x

10. East CE, Sherburn M, Nagle C, Said J, Forster D. Perineal pain following childbirth: Prevalence, effects on postnatal recovery and analgesia usage. Midwifery [Internet]. 2012 Feb [cited 2020 Nov 23];28(1):93-7. Available from: https://linkinghub.elsevier. com/retrieve/pii/S0266613810001889

11. Naviba S, Abedian Z, Steen-Greaves M. Effectivness of cooling gel pads and ice packs on perineal pain. Br J Midwifery. 2009 Nov;17(11):724-9.

12. Steen M. 'I can't sit down' - easing genital tract trauma. Br J Midwifery. 2005 May;13(5):311-4.

13. Senol DK, Aslan E. The Effects of Cold Application to the Perineum on Pain Relief After Vaginal Birth. Asian Nurs Res (Korean Soc Nurs Sci) [Internet]. 2017 Dec 1 [cited 2020 Feb 10];11(4):276-82. Available from: https://linkinghub.elsevier.com/retrieve/pii/ S1976131717301317

14. MR Petersen. Review of interventions to relieve postpartum pain from perineal trauma. journals.Iww.com [Internet]. 2011 [cited 2019 Nov 25]; Available from: https://journals. Iww.com/mcnjournal/FullText/2011/07000/ Review_of_Interventions_to_Relieve_ Postpartum_Pain.8.aspx

15. Melvia Girsang B, Afi Darti N, Simamora R, Indriani Karo E, Keperawatan Maternitas Dan Anak D, Keperawatan F, et al. Gambaran Karakteristik Luka Perineum Pada Ibu Post Partum Dengan Hidroterapi Sitz Bath. J Keperawatan Respati Yogyakarta [Internet]. 2019 [cited 2020 Nov 23];6(3):666-71. Available from: http://nursingjurnal.respati. ac.id/index.php/JKRY/index
16. Robin Petersen M. Review of interventions to relieve postpartum pain from perineal trauma. MCN Am J Matern Nurs [Internet]. 2011 Jul [cited 2020 Feb 10];36(4):241-5. Available from: http://content.wkhealth.com/ linkback/openurl?sid=WKPTLP:landingpage \&an=00005721-201107000-00008

17. Abed H, Mohamed E-A, Saied ElNagger N. Effect of Self Perineal Care Instructions on Episiotomy Pain and Wound Healing of Postpartum Women. J Am Sci. 2012;88(66):640-50.

18. Steen M, Briggs M, King D. Alleviating postnatal perineal trauma: To cool or not to cool? [Internet]. Vol. 14, British Journal of Midwifery. MA Healthcare Ltd; 2006 [cited 2020 Feb 10]. p. 304-8. Available from: http://www.magonlinelibrary.com/ doi/10.12968/bjom.2006.14.5.21056

19. Ousey K, Cook L. Understanding the importance of holistic wound assessment. Pract Nurs [Internet]. 2011 Jun [cited 2020 Feb 13];22(6):308-14. Available from: http:// www.magonlinelibrary.com/doi/10.12968/ pnur.2011.22.6.308

20. IJSR-INTERNATIONAL JOURNAL OF SCIENTIFIC RESEARCH Effectiveness of Cooling Gel Pads on Episiotomy Pain Reduction and Promotion of Wound Healing Among Postnatal Mothers.

21. Das S. Evaluative study to assess the effectiveness of infrared therapy on episiotomy wound. Siksha O' Anusandhan Univ. 2012;

22. Mohamed Khalefa El-Saidy T, MohamedNabil Aboushady R, Fawzy Abbas Soliman H. INTERNATIONAL JOURNAL OF NURSING DIDACTICS Effect of Applying Crushed Ice Gel Pads on Episiotomy Pain and Wound Healing Among Postpartum Primiparous Women. Int J Nurs Didact [Internet]. 2018 [cited 2020 Feb 10];8(07). Available from: http://innovativejournal.in/index.php/ijnd 
23. Webb S, Sherburn M, Ismail KMK. Managing perineal trauma after childbirth. Med J. 2014;349:24.

24. Boyle R, Hay-Smith EJC, Cody JD, Mørkved S. Pelvic floor muscle training for prevention and treatment of urinary and fecal incontinence in antenatal and postnatal women: A short version Cochrane review. Neurourol Urodyn [Internet]. 2014 Mar [cited 2020 Sep 7];33(3):269-76. Available from: http://doi.wiley.com/10.1002/nau.22402. 